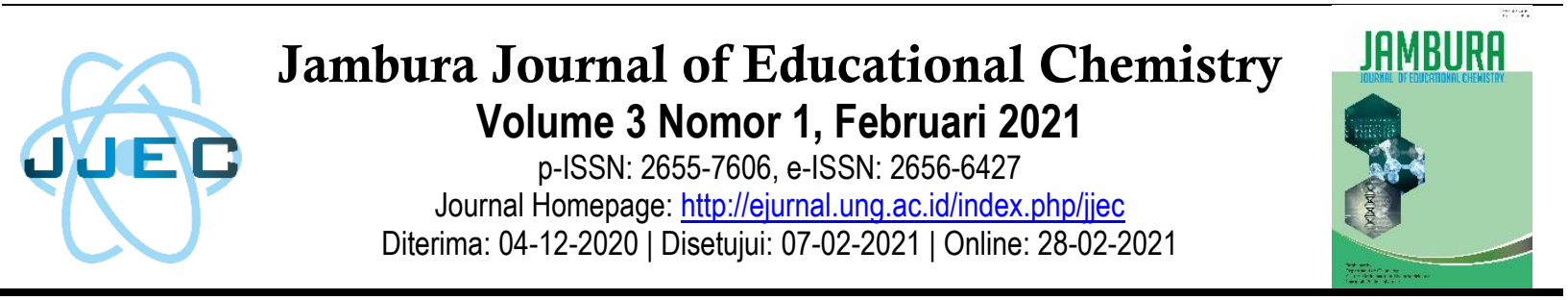

\title{
Pengaruh Disiplin Belajar Terhadap Prestasi Belajar Kimia Siswa Kelas X SMA Swasta di Samarinda
}

\author{
Siti Nurjanah1, Ratna Kusumawardani², Iis Intan Widiyowati ${ }^{3}$ \\ 1,2,3 Jurusan Pendidikan Kimia dan Ilmu Pengetahuan Alam, Fakultas Keguruan dan Ilmu \\ Pendidikan, Universitas Mulawarman, Jl. Muara Pahu Kampus Gn. Kelua, Samarinda, P.O.BOX \\ 74123, Indonesia \\ e-mail: ${ }^{1}$ nursitijanah@gmail.com
}

\begin{abstract}
Abstrak
Penelitian ini bertujuan untuk mengetahui pengaruh disiplin belajar terhadap prestasi belajar kimia siswa kelas X SMA Swasta di Samarinda. Jenis penelitian ini adalah analisis deskriptif. Populasi dalam penelitian ini adalah seluruh siswa kelas X SMA Swasta di Samarinda. Teknik pengambilan sampel dilakukan dengan cara probability sampling dengan metode cluster random sampling dan diperoleh sampel sebanyak 212 siswa. Berdasarkan hasil analisis data secara deskriptif diperoleh skor rata-rata disiplin belajar siswa adalah 35,38 tergolong dalam kategori sedang dan prestasi belajar kimia siswa adalah 34,91 tergolong dalam kategori sedang. Dari hasil analisis regresi linier sedehana $\mathrm{Y}=\mathrm{a}+\mathrm{bX}$, maka diperoleh persamaan regresinya $\mathrm{Y}=38,707+0,601 \mathrm{X}$, uji hipotesis uji $\mathrm{t}$ diperoleh signifikansi $0,000<0,05$ menunjukkan bahwa terdapat pengaruh positif disiplin belajar terhadap prestasi belajar kimia siswa. Adapun kontribusi pengaruh disiplin belajar terhadap prestasi belajar kimia sebesar $12,4 \%$. Berdasarkan hasil penelitian menunjukkan bahwa terdapat pengaruh positif atau signifikan disiplin belajar terhadap prestasi belajar kimia siswa kelas X SMA Swasta di Samarinda.
\end{abstract}

Kata kunci: Disiplin Belajar, Prestasi Belajar Kimia

\section{PENDAHULUAN}

Kimia adalah ilmu yang mempelajari materi baik itu sifat, perubahan, reaksi, dan energi yang menyertai perubahan materi tersebut. Pelajaran kimia di Sekolah dianggap salah satu mata pelajaran yang sulit untuk dipahami oleh siswa. Hal ini disebabkan pada mata pelajaran kimia memuat konsep-konsep yang abstrak dengan tingkat kesukaran yang tinggi, sehingga diperlukan disiplin belajar yang tinggi untuk mencapai ketuntasan yang diinginkan.

Menurut Arikunto (dalam Sumantri, 2010) disiplin ialah kepatuhan individu dalam mematuhi peraturan, norma, tata tertib yang disebabkan oleh dorongan kesadaran yang ada dalam hatinya. Sedangkan menurut Prijodarminto (dalam Sukmanasa, 2016) disiplin belajar merupakan sebuah kondisi yang diciptakan dan dibentuk melalui proses belajar siswa dari serangkaian perilaku dan sikap yang menunjukkan nilai-nilai kepatuhan, ketaatan, keteraturan dan ketertiban.

Faktor-faktor yang mempengaruhi disiplin belajar yaitu faktor internal dan faktor eksternal. Faktor internal berasal dari diri siswa sendiri dan dapat mempengaruhi disiplin belajarnya. Dalam hal ini faktor internal terbagi menjadi dua yakni keadaan fisik dan psikis yang mempengaruhi pembentukan disiplin diri. Sedangkan faktor eksternal berasal dari lingkungan luar yang dapat mempengaruhi disiplin belajar siswa. Faktor eksternal tersebut meliputi kebiasaan keluarga, penataan tata tertib sekolah dan kondisi masyarakat (Yuliantika, 2017). 
Disiplin belajar tentunya memberikan pengaruh bagi aktifitas dan juga prestasi yang diperoleh siswa. Dengan diterapkannya kedisiplinan maka siswa dituntut untuk lebih teratur dan tertib dalam segala hal termasuk juga dalam proses belajar mengajar sehingga diharapakan dengan diterapkannya kedisiplinan maka siswa akan memperoleh prestasi belajar yang memuaskan dalam pembelajaran kimia.

Prestasi belajar menunjukkan hasil usaha belajar yang dicapai peserta didik selama mereka melakukan kegiatan belajar di sekolah yang pada umumnya ditunjukkan dengan bentuk nilai. Prestasi belajar berfungsi sebagai indikator keberhasilan siswa dalam suatu mata pelajaran. Menurut Zainal (2016) Prestasi belajar adalah indikator kualitas dan kuantitas pengetahuan yang dimiliki siswa (peserta Didik).

Pencapaian prestasi belajar dipengaruhi oleh berbagai faktor, yaitu faktor internal dan faktor eksternal. Faktor internal merupakan kemampuan yang dimiliki dan ada pada diri siswa seperti kondisi fisik, sikap belajar, bakat, minat dan disiplin. Sedangkan faktor eksternal seperti lingkungan keluarga mencakup cara orang tua mendidik, perhatian orang tua, keadaan ekonomi keluarga, lingkungan sekolah meliputi kurikulum, sistem pengajaran dan metode guru mengajar (Slameto, 2010). Kedua faktor tersebut saling mendukung sehingga tercipta kondisi belajar yang optimal dan mencapai prestasi belajar yang tinggi.

Berdasarkan uraian di atas peneliti ingin mengetahui "Apakah terdapat pengaruh disiplin belajar terhadap prestasi belajar kimia siswa kelas X SMA Swasta di Samarinda”.

\section{METODE PENELITIAN}

\section{Jenis Penelitian}

Jenis penelitian ini merupakan penelitian kuantitatif dengan metode penelitian menggunakan metode deskriptif.

\section{Waktu dan Tempat Penelitian}

Penelitian ini dilaksanakan pada tanggal 24 Februari 2020 sampai tanggal 27 Maret 2020. Penelitian dilaksanakan dikelas X SMA Swasta di Samarinda.

\section{Target/Subjek Penelitian}

Populasi dalam penelitian ini adalah seluruh siswa kelas X SMA Syaichona cholil, Alkhairiyah, Nabil Husein, Budi Luhur, IT Granada, dan Plus Melati di Samarinda yang mempelajari kimia. Teknik pengambilan sampel menggunakan teknik Cluster Random Sampling.

Data, Instrumen, dan Teknik Pengumpulan

Data

Data yang diperoleh dalam penelitian ini adalah berupa data angket yang berisi tentang disiplin belajar dengan jumlah pernyataan sebanyak 30 pernyataan. Intrumen yang digunakan dalam penelitian ini yaitu angket. Teknik pengumpulan data yang digunakan dalam penelitian yaitu angket dan dokumentasi.

Data yang diperoleh dalam penelitian ini dianalisis dengan analisis deskriptif dan analisis regresi sederhana.

Data yang diperoleh dari suatu penelitian dianalisis terlebih dahulu secara benar agar dapat ditarik suatu kesimpulan yang merupakan jawaban yang tepat dari permasalahan yang diajukan. Metode yang digunakan dalam penelitian ini yaitu:

\section{Metode Analisis Deskriptif}

Statistik deskriptif yang digunakan dalam penelitian ini meliputi tabel frekuensi yang memuat kolom persentase, nilai rata-rata, standar deviasi, skor tertinggi dan skor terendah. Hal ini dilakukan untuk merincikan skor dari masing-masing variabel, baik variabel bebas yaitu disiplin belajar maupun variabel terikat yaitu prestasi belajar kimia siswa.

Untuk mengetahui kecenderungan hasil pengamatan masing-masing variabel bebas maka dikelompokkan menjadi lima kategori dengan interpretasi skor pada Tabel 1 berikut:

Tabel 1. Kriteria Interval Skor

\begin{tabular}{cc}
\hline Interval & Kriteria \\
\hline$\mu \leq-1,5 \sigma$ & Kategori Sangat Rendah \\
$-1,5 \sigma<\mu \leq-0,5 \sigma$ & Kategori Rendah \\
$-1,5 \sigma<\mu \leq+0,5 \sigma$ & Kategori Sedang \\
$+0,5 \sigma<\mu \leq+1,5 \sigma$ & Kategori Tinggi \\
$+1,5 \sigma<\mu$ & Kategori Sangat Tinggi \\
\hline
\end{tabular}

(Azwar, 2014)

Keterangan:

$\mu=$ Rata-rata variabel

$\sigma=$ Standar deviasi 
Penggunaan interpretasi skor tersebut dilakukan untuk mengungkapkan skor dan pengkategorian dari variabel bebas yaitu disiplin belajar, dan variabel terikat yaitu prestasi belajar kimia yang digunakan dalam penelitian ini.

\section{Metode Analisis Regresi}

a. Uji Normalitas

Uji normalitas merupakan metode untuk menentukan dan menguji variabel terikat dan variabel bebas berdistribusi normal ataukah tidak. Model regresi yang baik dapat dilihat pada model yang berdistribusi normal atau yang mendekati normal.

One sampel Kolmogorov-Smirnov Test (dengan program SPSS) merupakan salah satu cara yang banyak digunakan untuk menguji normalitas. Diantaranya adalah sampel yang akan dipakai untuk analisis haruslah berasal dari populasi yang berdistribusi normal dengan tingkat signifikansi $\alpha=$ $5 \%(0,05)$, jika signifikansi $<0,05$ maka distribusi data dapat dikatakan tidak normal. Sebaliknya jika signifikansi > 0,05 maka distribusi data dapat dikatakan normal.

b. Uji Linieritas

Uji linieritas merupakan metode untuk menentukan dan menguji variabel terikat dan variabel bebas memiliki hubungan yang linier secara signifikan atau tidak.

Deviation from Linearity (dengan program SPSS) merupakan salah satu cara yang digunakan untuk menguji linieritas. Kelinieran antara variabel dapat dilihat apabila nilai Deviation from Linearity $>0.05$, dengan demikian terdapat hubungan yang linier secara signifikan antara variabel terikat dan variabel bebas. Sebaliknya, apabila nilai Deviation from Linearity $<0,05$ maka tidak terdapat hubungan linier secara signifikan antara variabel terikat dan variabel bebas.

c. Analisis Regresi Sederhana

Analisis regresi sederhana merupakan analisis yang memperkirakan secara sistematis tentang hal yang paling memungkinkan untuk terjadi di masa depan yang didasarkan pada informasi masa lalu dan sekarang, sehingga kemungkinan kesalahan dapat diperkecil (Riduwan, 2011).
Rumus Regresi Sederhana:

$\mathrm{Y}=\mathrm{a}+\mathrm{bX}$

Keterangan:

$\mathrm{Y} \quad=$ prestasi belajar

a $\quad=$ konstanta

$\mathrm{b}=$ koefisien disiplin belajar

$\mathrm{X}=$ disiplin belajar

Uji $\mathrm{t}$ atau parsial digunakan untuk mengetahui kemaknaan pengaruh variabel bebas terhadap variabel terikat secara parsial. Uji $t$ dilakukan dengan program SPSS. Kriteria pengujiannya jika nilai signifikan $\mathrm{t}<0,05$ maka hipotesis $\mathrm{H}_{\mathrm{a}}$ diterima dan ada pengaruh disiplin belajar terhadap prestasi belajar sedangkan jika nilai signifikan $\mathrm{t}>0,05$ maka hipotesis $\mathrm{H}_{0}$ ditolak dan tidak ada pengaruh disiplin belajar terhadap prestasi belajar.

Koefisien determinasi digunakan untuk mengukur seberapa jauh pengaruh yang diberikan variabel bebas atau variabel independent (X) terhadap variabel terikat atau variabel dependent (Y), dengan kata lain, nilai koefisien determinasi atau $\left(\mathrm{R}^{2}\right)$ berguna untuk memprediksi dan melihat seberapa besar kontribusi pengaruh yang diberikan variabel $\mathrm{X}$ secara simultan (bersama-sama) terhadap variabel $\mathrm{Y}$.

\section{HASIL DAN PEMBAHASAN}

Berdasarkan hasil penelitian yang telah dilaksanakan terhadap variabel bebas disiplin belajar (X) dan variable terikat prestasi belajar kimia (Y). Data variabel disiplin belajar di diperoleh dari instrumen penelitian berupa angket berjumlah 30 pernyataan yang disebar kepada 212 responden untuk mengetahui pengaruh disiplin belajar kimia di sekolah sedangkan data prestasi belajar kimia diperoleh dari data nilai kimia siswa semester sebelumnya. Data yang diperoleh dideskripsikan sebagai berikut:

1. Disiplin belajar

Disiplin belajar siswa merupakan disiplin dalam mentaati kegiatan belajar dan tata tertib disekolah. Berdasarkan hasil analisis secara keseluruhan diperoleh variabel disiplin belajar tergolong dalam kategori sedang, dapat dilihat pada tabel 2 . 
Tabel 2. Distribusi Frekuensi Disiplin Belajar

\begin{tabular}{|c|c|c|c|}
\hline \multicolumn{2}{|c|}{$\begin{array}{l}\text { Skor Disiplin } \\
\text { Belajar Kimia }\end{array}$} & \multirow[t]{2}{*}{ Frekuensi } & \multirow{2}{*}{$\begin{array}{c}\text { Persentase } \\
(\%)\end{array}$} \\
\hline Interval & Kategori & & \\
\hline $\begin{array}{c}X \leq \\
56,60\end{array}$ & $\begin{array}{l}\text { Sangat } \\
\text { Rendah }\end{array}$ & 16 & 7,55 \\
\hline $\begin{array}{c}56,60< \\
X \leq \\
66,20\end{array}$ & Rendah & 48 & 22,64 \\
\hline $\begin{array}{c}66,20< \\
X \leq \\
75,80\end{array}$ & Sedang & 75 & 35,38 \\
\hline $\begin{array}{c}75,80< \\
X \leq \\
85,40\end{array}$ & Tinggi & 60 & 28,30 \\
\hline $\begin{array}{c}85,40< \\
X\end{array}$ & $\begin{array}{l}\text { Sangat } \\
\text { Tinggi }\end{array}$ & 13 & 6,13 \\
\hline \multicolumn{2}{|c|}{ Jumlah } & 212 & 100,00 \\
\hline
\end{tabular}

Pada Tabel 2 di atas diperoleh 16 siswa berada pada kategori sangat rendah dengan persentase $7,55 \%, 48$ siswa berada pada kategori rendah dengan persentase $22,64 \%, 75$ siswa berada pada kategori sedang dengan persentase 35,38\%, 60 siswa berada pada kategori tinggi dengan persentase 28,30\%, dan 13 siswa berada pada kategori sangat tinggi dengan persentase $6,13 \%$. Berdasarkan data tersebut dapat dlilihat bahwa disiplin belajar tergolong dalam kategori sedang. Untuk lebih jelasnya dapat dilihat pada analisis deskriptif dari setiap indikator yang meliputi disiplin masuk sekolah, disiplin dalam persiapan belajar kimia, disiplin dalam mengikuti pelajaran kimia di sekolah, disiplin dalam mengerjakan tugas kimia dan disiplin belajar kimia di rumah.

2. Prestasi belajar

Prestasi belajar merupakan keberhasilan usaha yang dicapai setelah memperoleh pengalaman belajar atau mempelajari sesuatu. Berdasarkan analisis secara keseluruhan diperoleh variabel prestasi belajar dalam kategori sedang, seperti yang dapat dilihat pada Tabel 3 .
Tabel 3. Distribusi Frekuensi Prestasi Belajar Kimia

\begin{tabular}{|c|c|c|c|}
\hline \multicolumn{2}{|c|}{$\begin{array}{c}\text { Skor Prestasi Belajar } \\
\text { Kimia }\end{array}$} & \multirow{2}{*}{ Frekuensi } & \multirow{2}{*}{$\begin{array}{c}\text { Persentase } \\
\quad(\%)\end{array}$} \\
\hline Interval & Kategori & & \\
\hline$X \leq 60$ & $\begin{array}{l}\text { Sangat } \\
\text { rendah }\end{array}$ & 16 & 7,55 \\
\hline $60<X \leq 70$ & Rendah & 50 & 23,58 \\
\hline $70<X \leq 80$ & Sedang & 74 & 34,91 \\
\hline $80<X \leq 90$ & Tinggi & 56 & 26,42 \\
\hline $90<\mathrm{X} \leq 100$ & $\begin{array}{l}\text { Sangat } \\
\text { tinggi }\end{array}$ & 16 & 7,55 \\
\hline \multicolumn{2}{|c|}{ Jumlah } & 212 & 100,00 \\
\hline
\end{tabular}

Terlihat pada Tabel 3 diperoleh 16 siswa berada pada kategori sangat rendah dengan persentase $7,55 \%, 50$ siswa berada pada kategori rendah dengan persentase $23,58 \%, 74$ siswa berada pada kategori sedang dengan persentase 34,91\%, 56 siswa berada pada kategori tinggi dengan persentase 26,42\% dan 16 siswa berada pada kategori sangat tinggi dengan persentase $7,55 \%$. Berdasarkan data tersebut, maka prestasi belajar siswa pada mata pelajaran kimia berada pada kategori sedang.

3. Uji Prasyarat Analisis

a. Uji normalitas

Uji Kolmogorov-Smirnov (K-S) merupakan uji normalitas yang digunakan dalam penelitian ini. Dalam uji Kolmogorov-Smirnov (K-S) apabila nilai probabilitas > 0,05, maka data yang diperoleh berasal dari populasi yang berdistribusi normal, namun apabila nilai probabilitas $<0,05$, maka data yang diperoleh berasal dari populasi yang tidak berdistribusi normal. Hasil uji normalitas dapat dilihat pada Tabel 4 .

Tabel 4. Hasil Uji Normalitas

\begin{tabular}{cccc}
\hline Model & $\begin{array}{c}\text { Probabil } \\
\text { ity (p) } \\
\text { atau sig }\end{array}$ & Kriteria & Simpulan \\
\hline $\begin{array}{c}\text { Unstandardi } \\
\text { zed } \\
\text { Residual }\end{array}$ & 0,200 & $\mathrm{p}>0,05$ & $\begin{array}{c}\text { Data } \\
\text { berdistribusi } \\
\text { normal }\end{array}$ \\
\hline
\end{tabular}


Berdasarkan hasil uji Kolmogorov-Smirnov pada tabel diatas diketahui bahwa nilai signifikansi atau probabilitas yaitu 0,200 lebih besar dari 0,05 sehingga dapat disimpulkan bahwa data berasal dari populasi yang berdistribusi normal.

b. Uji linieritas

Deviation from Linearity (dengan program SPSS) merupakan salah satu cara yang digunakan untuk menguji linieritas. Kelinieran anatara variabel dapat dilihat jika nilai Deviation from Linearity > 0.05 maka ada hubungan yang linier secara signifikan antara variabel bebas dan variabel terikat. Sebaliknya jika nilai Deviation from Linearity < 0,05 maka tidak ada hubungan yang linier secara signifikan antara variabel bebas dan variabel terikat. Hasil uji linieritas dapat dilihat pada Tabel 5.

Tabel 5. Hasil Uji Linieritas

\begin{tabular}{ccccc}
\hline $\mathbf{N}$ & Df & $\begin{array}{c}\text { Mean } \\
\text { Square }\end{array}$ & F & Sig (p) \\
\hline 212 & 1 & 22,839 & 1,268 & 0,198 \\
\hline \multicolumn{4}{r}{}
\end{tabular}

Berdasarkan data tabel 5, diperoleh nilai signifikansi deviation from linearity adalah 0,198 lebih besar dari 0,05. Maka dapat disimpulkan bahwa ada hubungan linier secara signifikan antara variabel disiplin belajar (X) dengan variabel prestasi belajar (Y).

4. Analisis Akhir (Pengujian Hipotesis)

Pengujian hipotesis yang digunakan dalam penelitian ini menggunakan analisis regresi sederhana yang diuji secara simultan maupun parsial dengan bantuan program SPSS. Untuk memudahkan dalam menginterpretasikan persamaan regresi, maka hasil analisis tersebut telah dirangkum dalam Tabel 6.

Tabel 6. Hasil Analisis Regresi Sederhana

\begin{tabular}{cccc|}
\hline Variabel & $\begin{array}{c}\text { Koefisien } \\
\text { regresi }\end{array}$ & $\begin{array}{c}\mathbf{t}- \\
\text { hitung }\end{array}$ & $\begin{array}{c}\text { Probabilit } \\
\text { as atau } \\
\text { Sig }\end{array}$ \\
\hline Konstanta & 38,707 & 9.058 & 000 \\
Disiplin belajar & 0,601 & 10,669 & \\
Fhit $_{\text {hit }}$ & 113,825 & & \\
Sig.F & 000 & & \\
$\mathrm{R}$ & 0,352 & & \\
$\mathrm{R}^{2}$ & 0,124 & & \\
\hline
\end{tabular}

Sumber: Hasil SPSS
Pada penelitian ini digunakan persamaan regresi linier sederhana sebagai berikut: $\mathrm{Y}=\mathrm{a}+$ bX

Berdasarkan hasil perhitungan dengan menggunakan SPSS, diperoleh harga koefisien regresi $a=38,707$ dan $b=0,601$. Koefisien regresi bernilai positif, maka dengan demikian dapat dikatakan bahwa disiplin belajar (X) berpengaruh positif terhadap prestasi belajar (Y). Sehingga persamaan regresinya adalah

$$
\mathrm{Y}=38,707+0,601 \mathrm{X}
$$

a. Uji t

Berdasarkan Tabel 6 dapat dilihat pengaruh disiplin belajar terhadap prestasi belajar kimia yaitu diperoleh nilai $t_{\text {hitung }}=10,669$ dengan taraf signifikansi statistik sebesar 0,000 . Hal ini berarti $p$ $<\alpha$ yaitu $0,000<0,05$ dan diperkuat dengan nilai $t_{\text {hitung }}>t_{\text {tabel }}$ yaitu 10,669 $>1,971$, maka Ha diterima dan $\mathrm{H}_{0}$ ditolak. Dapat disimpulkan bahwa terdapat pengaruh disiplin belajar terhadap prestasi belajar kimia.

b. Koefisien Determinasi

Berdasarkan hasil analisis yang terdapat pada Tabel 6 diperoleh koefisien determinasi $\left(\mathrm{R}^{2}\right)$ $0,124 \%$ hal ini menunjukkan bahwa disiplin belajar siswa mempunyai pengaruh sebesar $12,4 \%$ bagi prestasi belajar kimia. Sedangkan sisanya sebesar $87,6 \%$ dipengaruhi oleh faktor lain.

Berdasarkan hasil penelitian ini membuktikan bahwa variabel disiplin belajar berpengaruh positif dan signifikan terhadap prestasi belajar kimia siswa kelas X SMA Swasta di Samarinda. Hal ini menunjukkan bahwa peningkatan dan penurunan pada variabel disiplin belajar di dalam diri siswa, dapat berpengaruh terhadap nilai atau prestasi yang dapat siswa raih. Pengaruh variabel tersebut ditunjukkan dengan koefisien determinasi yang merupakan kontribusi pengaruh variabel disiplin belajar sebesar $12,4 \%$ sedangkan sisanya sebesar $87,6 \%$ dipengaruhi oleh faktor lain. Nilai probabilitas yang diperoleh lebih kecil dari $5 \%$ yaitu $0,000<0,05$ yang memiliki arti bahwa variabel disiplin belajar berpengaruh positif signifikan terhadap prestasi belajar kimia.

Hasil penelitian tersebut sesuai dengan pendapat Harun et al., (2015), menerangkan mengenai siswa yang disiplin dalam belajar secara 
tidak langsung akan memiliki prestasi belajar yang tinngi, namun sebaliknya apabila siswa tidak disiplin dalam belajar cenderung prestasi belajar siswa tersebut tidak akan memuaskan. Dengan adanya pembiasaan pada diri siswa untuk terus belajar maka akan meningkatkan rasa disiplin belajarnya dan mendapatkan prestasi belajarnya.

Berdasarkan hasil penelitian dan pendapat diatas, maka dapat disimpulkan bahwa disiplin belajar yang dimiliki siswa dapat mempengaruhi prestasi belajar siswa tersebut. Kedisiplinan merupakan hal yang erat kaitannya dengan pembelajaran, karena di dalan belajar di sekolah siswa juga dituntun untuk rajin dan tekun dalam mengikuti pembelajaran yang ada, selain itu siswa juga dituntun untuk mengikuti peraturan sekolah dengan tertib dan teratur agar tercipta kegiatan pembelajaran yang baik dan membuat siswa dapat berkonsentrasi untuk belajar.

\section{KESIMPULAN}

Berdasarkan hasil penelitian dan pembahasan dapat disimpulkan bahwa: Terdapat pengaruh positif atau signifikan disiplin belajar terhadap prestasi belajar kimia kelas X SMA Swasta di Samarinda serta memberikan kontribusi bersamasama sebesar $12,4 \%$.

\section{UCAPAN TERIMA KASIH}

Ucapan terimakasih diberikan kepada Kepala Sekolah SMA Syaichona Cholil, Alkhairiyah, Nabil Husein, Budi luhur, IT Granada dan Plus Melati di Samarinda yang telah memberikan ijin untuk melakukan penelitian.

\section{DAFTAR PUSTAKA}

Azwar, S. (2014). Metode Penelitian, Yogyakarta: Pustaka Pelajar, 2012. Reliabilitas Dan Validitas Edisi, 4.

Harun, A. Y., Sumardi, \& Sukmanasa, E. (2015). Jurnal Program Studi Pendidikan Guru Sekolah Dasar FKIP Universitas Pakuan. Universitas Pakuan.

Riduwan, S. (2011). Pengantar Statistika untuk penelitian pendidikan, sosial, ekonomi, komunikasi dan bisnis. Cetakan Ke-4 Bandung: Alfabeta.

Slameto. (2010). Belajar dan Faktor-faktor Yang Mempengaruhinya. PT Rineka Cipta.

Sukmanasa, E. (2016). Hubungan antara Disiplin Belajar dengan Hasil Belajar pada Mata Pelajaran Ilmu Pengetahuan Sosial. Jurnal Kreatif: Jurnal Kependidikan Dasar, 7(1).

Sumantri, B. (2010). Pengaruh Disiplin Belajar Terhadap Prestasi Belajar Siswa Kelas XI SMK PGRI 4 Ngawi Tahun Pelajaran 2009/2010. Media Prestasi, VI(3), 117-126.

Yuliantika, S. (2017). Analisis Faktor-Faktor Yang Mempengaruhi Disiplin Belajar Siswa Kelas X, XI, Dan XII Di SMA Bhakti Yasa Singaraja Tahun Pelajaran 2016/2017. Jurnal Pendidikan Ekonomi Undiksha, 9(1), 35-44.

Zainal, A. (2016). Evaluasi Pembelajaran: Prinsip, Teknik, dan Prosedur. Bandung: PT Remaja Rosdayakarya. 